"Mircea cel Batran" Naval Academy Scientific Bulletin, Volume XIX - 2016 - Issue 1

Published by "Mircea cel Batran" Naval Academy Press, Constanta, Romania // The journal is indexed in:

PROQUEST / DOAJ / DRJI / JOURNAL INDEX / I2OR / SCIENCE LIBRARY INDEX / Google Scholar / Crossref /

Academic Keys / ROAD Open Access / OAJI / Academic Resources / Scientific Indexing Services / SCIPIO

\title{
CORROSION RATE OF STEELS DX51D AND S220GD IN DIFFERENT CORROSION ENVIRONMENT
}

\author{
Alina Crina CIUBOTARIU ${ }^{1}$ \\ Gina Genoveva ISTRATE ${ }^{2}$ \\ 1,2Lecturer PhD. Chem. Dunarea de Jos University of Galati, Engineering Faculty, Galati, Romania \\ ${ }^{2}$ Lecturer PhD. Eng. Dunarea de Jos University of Galati, Engineering Faculty, Galati, Romania \\ Email address: aciubotariu@ugal.ro
}

\begin{abstract}
Corrosion in the marine environment is an important issue because the costs causes by marine corrosion increased year upon year. It is necessary a correctly approach to materials selection, protection and corrosion control to reduce this burden of wasted materials, wasted energy and wasted money. Many different types of corrosion attack can be observed to structures, ships and other equipment used in sea water service. Shipping containers are exposed to various corrosive mediums like as airborne salt, industrial pollutants, rain and saltwater. Transport damage during loading onto and unloading off trucks, train beds and ships breaches the paint coating which further contributes to corrosion. The result is shortened container life and high costs for container repair or replacement. The paper intends to evaluate, by gravimetric method, the corrosion rate and corrosion penetration rate of two types of carbon steel DX51D and S220GD. Carbon steel DX51D and hot-dip galvanized steel S220GD are used in marine and industrial applications for buildings cargo vessels, container ships and oil tankers. For testing it was used different corrosive environments: $5 \%$ $\mathrm{NaOH}$ solution; $5 \% \mathrm{HCL}$ solution and $0.5 \mathrm{M} \mathrm{NaCl}$ solution. The samples were immersed in $400 \mathrm{~mL}$ of testing solution for exposure period of 28 days. Periodically at 3 days, 7 days, 14 days, 21 days and 28 days was measured de mass loss and evaluate the corrosion rate and corrosion stability coefficient. The steel DX51D was stable in $5 \% \mathrm{NaOH}$ solution for 28 days, the values of corrosion stability coefficient was 7 after 3 days and 6 after 28 days of immersion in corrosive medium. In 5\% HCL solution steels DX51D and S220GD was completely corroded in 21 days with a corrosion stability coefficient equal with 9 for 7 days and 8 for 21 days of immersion in corrosive solution. It was observed a good resistance for 3 days in $0.5 \mathrm{M} \mathrm{NaCl}$ solution with a corrosion stability coefficient equal with 5 , but after that stability of the steel decrease in time and corrosion stability coefficient increase at 6 . For steel S220GD it was found a corrosion stability coefficient equal with 6 after 21 days of immersion and 5 after 28 days of immersion in $5 \% \mathrm{NaOH}$ solution. In $0.5 \mathrm{M} \mathrm{NaCl}$ solution the corrosion stability coefficient at steel S220GD was 6 for all period tested.
\end{abstract}

Keywords: DX51D carbon steel, S220GD hot-dip galvanized steel, corrosion environment, corrosion rate, corrosion stability coefficient

\section{INTRODUCTION}

Corrosion is well defined as the destructive attack on a material by reaction with its environment. Corrosive damage affects all industries, communities and, therefore, all men, without a group to feel responsible to invest in research programs of benefit to all. Knowing the corrosion behavior (attack speed, type of corrosion, rate of corrosion, penetration index etc.) materials in different environmental conditions, it is a condition preliminary to applying a corrosion control methods or selecting a material suitable for specific environmental conditions but define precise control factor is not always possible.

The term 'corrosion aqueous' describes most problems encountered in contact with sea water not only comprehensive and evolving how corrosion due to exposure ships and many other types of steel structures in atmospheric action or saline corrosion.
Corrosion of materials in marine environments is dependent on various factors such as material composition, $\mathrm{pH}$, salinity, temperature, oxygen content, seawater chemistry, microbiological organisms, surface roughness, pollution and contamination, etc. Corrosion performance is not always the determining factor when selecting materials even for aggressive marine conditions. The large range of alloys available has been developed as much for mechanical and physical properties as for corrosion characteristics [1 - 4]. Carbon steels generally presents surface defects, such as grain boundaries and inclusions, which are the preferred sites for the initiation of pitting corrosion $[5,6]$. Galvanized steel is widely employed in numerous engineering applications due to its resistance to corrosion. This improved corrosion behavior is given by the zinc coating in two steps: first, acting as physical barrier, and secondly, providing galvanic protection $[7,8]$. 
"Mircea cel Batran" Naval Academy Scientific Bulletin, Volume XIX - 2016 - Issue 1

Published by "Mircea cel Batran" Naval Academy Press, Constanta, Romania // The journal is indexed in: PROQUEST / DOAJ / DRJI / JOURNAL INDEX / I2OR / SCIENCE LIBRARY INDEX / Google Scholar / Crossref /

Academic Keys / ROAD Open Access / OAJI / Academic Resources / Scientific Indexing Services / SCIPIO

In practical, problems of corrosion it is important to know the real speed with which the process is carried. If the corrosion process has a very low rate of progress may be considered material is corrosion resistant. Corrosion can be judged quantitatively by calculating corrosion rate by gravimetric method [9-11].

Index weight is the most common way of expressing corrosion can be increased weight of the sample, through the formation of corrosion products (oxidation of metals) that remain adherent to metal or symbolize weight loss when corrosion products can be removed from the surface. Index weight introduces errors in gravimetric determination, because not knowing the exact chemical composition of corrosion products. The index used is therefore corresponds to weight loss, whose accuracy depends on the complete removal of corrosion products [12].

In literature exists reports about the mechanical properties of steels DX51D and S220GD, but investigation about corrosion behavior of these types of steel are limited [13].

In this paper, the corrosion behavior of carbon steel DX51D (continuously hot-dip coated strips and sheets of low carbon steel for cold forming) and conventional hot-dip galvanized steel S220GD (continuously hot-dip coated strips and sheets of structural steel) was studied. Corrosion parameters such as corrosion rate and penetration index for carbon steels in $5 \% \mathrm{HCl}$ solution, $5 \% \mathrm{NaOH}$ and $0.5 \mathrm{M} \mathrm{NaCl}$ were determined from weight loss measurement data. Corrosion stability coefficient of steel tested samples was evaluated function penetration index.

\section{MATERIALS AND METHODS}

Weight loss measurements were cared out on the steel tested samples abraded with different emery papers (grade 800, 1000 and 1200), washed with double distilled water, rinsed with ethanol and acetone, and then dried at room temperature. After weighing accurately, the specimens were immersed in beakers contained $250 \mathrm{~mL}$ with $5 \%$ $\mathrm{NaOH}, 5 \% \mathrm{HCl}$ and $0.5 \mathrm{M} \mathrm{NaCl}$.

After each immersion time (3, 7, 14, 21 and 28 days) the specimens were removed, polish with emery papers, washed in double distilled water, degreased with acetone, dried in warm air and reweighed. In order to obtain good reproducibility, experiments were carried out in triplicate.

The chemical composition of steel DX51D and steel S220GD are given in Table 1 and Table 2, respectively.

Tabel 1. Chemical composition of steel DX51D

\begin{tabular}{|c|c|c|c|c|c|}
\hline C\% & Mn\% & Si\% & P\% & S\% & Al\% \\
\hline 0.032 & 0.268 & 0.008 & 0.012 & 0.010 & 0.045 \\
\hline Cu\% & Cr\% & Ni\% & V\% & Mo\% & Ti\% \\
\hline 0.014 & 0.015 & 0.010 & 0.001 & 0.002 & 0.001 \\
\hline Nb\% & B $\%$ & As\% & $\mathrm{N}_{2} \%$ & & \\
\hline 0.001 & 0.0001 & 0.002 & 0.0059 & & \\
\hline
\end{tabular}

Tabel 2. Chemical composition of steel S220GD

\begin{tabular}{|c|c|c|c|c|c|}
\hline $\mathrm{C} \%$ & $\mathrm{Mn} \%$ & $\mathrm{Si} \%$ & $\mathrm{P} \%$ & $\mathrm{~S} \%$ & $\mathrm{Al} \%$ \\
\hline 0.041 & 0.2547 & 0.008 & 0.013 & 0.017 & 0.044 \\
\hline $\mathrm{Cu} \%$ & $\mathrm{Cr} \%$ & $\mathrm{Ni} \%$ & $\mathrm{~V} \%$ & $\mathrm{Mo} \%$ & $\mathrm{Ti} \%$ \\
\hline 0.023 & 0.019 & 0.011 & 0.001 & 0.001 & 0.001 \\
\hline $\mathrm{Nb} \%$ & $\mathrm{~B} \%$ & $\mathrm{As} \%$ & $\mathrm{~N}_{2} \%$ & & \\
\hline 0.001 & 0.0001 & 0.002 & 0.0066 & & \\
\hline
\end{tabular}

For preparing corrosive solutions $5 \% \mathrm{HCl}, 5 \%$ $\mathrm{NaOH}$ and $0.5 \mathrm{M} \mathrm{NaCl}$ it were used dilution of AR grade $35 \% \mathrm{HCl}$ with distilled water, sodium hydroxide (NaOH, Merck, 99\%) and sodium chloride ( $\mathrm{NaCl}$, Merck, 99\%).

From the initial and final weights of the samples, the loss of weights, the corrosion rate $\left(\mathrm{g} / \mathrm{m}^{2} \cdot \mathrm{h}\right)$ and penetration index ( $\mathrm{mm} /$ year) were calculated with the following equation $[14,15]$ :

$$
\begin{gathered}
\Delta m=m_{f}-m_{i} \\
v_{\text {cor }}=\frac{\Delta m}{S \cdot t}
\end{gathered}
$$

where $m_{f}$ is final weight of sample tested, $m_{i}$ is initial weight of sample tested, $\Delta \mathrm{m}$ is the loss of weight $(\mathrm{g}), \mathrm{S}$ is area of the samples tested $\left(\mathrm{m}^{2}\right), \mathrm{t}$ is immersion time in corrosive environment $(h)$.

$$
P=\frac{24 \cdot 365 \cdot v_{c o r}}{1000 \cdot \rho}=8.76 \cdot \frac{v_{c o r}}{\rho}
$$

where $P$ is penetration index, 24 represents hours on a day, 365 days number from an year, 1000 is the conversion factor of units; $\rho$ is density of tested materials $\left(\rho=7.87 \mathrm{~g} / \mathrm{cm}^{3}\right)$.

From values of corrosion rate and penetration index of tested samples in different corrosive solutions it was evaluated corrosion tendency of steels DX51D and S220GD using corrosion stability coefficient values [16].

\section{RESULTS AND DISCUSSION}

Figure 1 and Figure 2 presents the corrosion rate and penetration index of steel types DX51D and S220GD after 3 days of immersion in $5 \% \mathrm{NaOH}$, $5 \% \mathrm{HCl}$ and $0.5 \mathrm{M} \mathrm{NaCl}$. 
"Mircea cel Batran" Naval Academy Scientific Bulletin, Volume XIX - 2016 - Issue 1 Published by "Mircea cel Batran" Naval Academy Press, Constanta, Romania // The journal is indexed in: PROQUEST / DOAJ / DRJI / JOURNAL INDEX / I2OR / SCIENCE LIBRARY INDEX / Google Scholar / Crossref / Academic Keys I ROAD Open Access / OAJI / Academic Resources / Scientific Indexing Services / SCIPIO

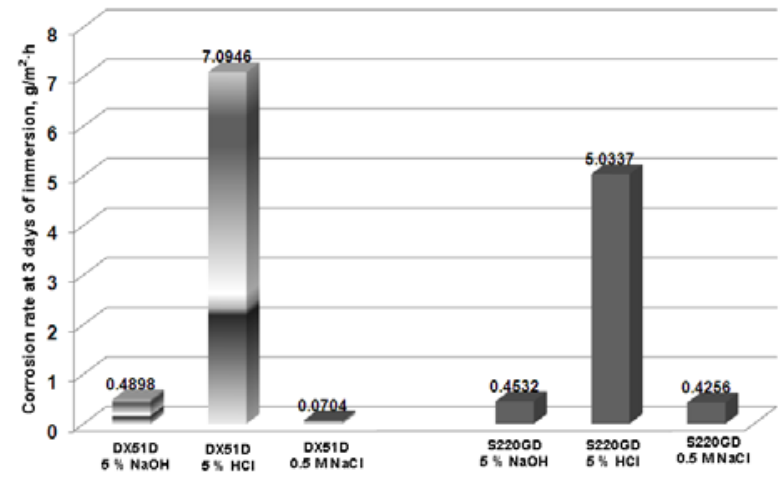

Figure 1. Corrosion rate of tested steels after 3 days of immersion in different corrosive solutions

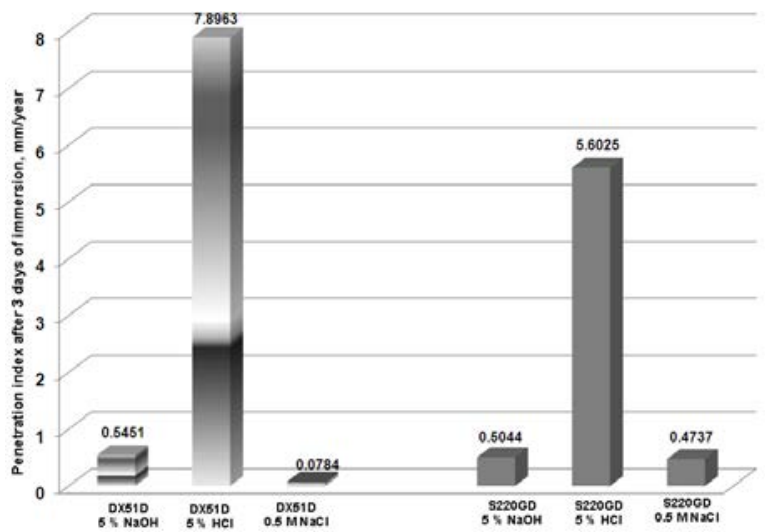

Figure 2. Penetration index of tested steels after 3 days of immersion in different corrosive solutions

From the values presented in Figs. 1 and 2 can be concluded that $5 \% \mathrm{HCl}$ solution was most corrosive media, a high value of corrosion rate was found for steel DX51D $\left(7.0946 \mathrm{~g} / \mathrm{m}^{2} \cdot \mathrm{h}\right)$. Corrosion rates were close values for DX51D in 5 $\% \mathrm{NaOH}, \mathrm{S} 220 \mathrm{GD}$ in $5 \% \mathrm{NaOH}$ and S220GD in $0.5 \mathrm{M} \mathrm{NaCl}$. A good corrosion resistance after 3 days of immersion in tested solutions was found for steel DX51D in $0.5 \mathrm{M} \mathrm{NaCl}$ with a value of corrosion rate of $0.0704 \mathrm{~g} / \mathrm{m}^{2} \cdot \mathrm{h}$.

Values of corrosion rate and penetration index of DX51D and S220GD after 7 days of immersion in $5 \% \mathrm{NaOH}, 5 \% \mathrm{HCl}$ and $0.5 \mathrm{M} \mathrm{NaCl}$ are presented in Figure 3 and Figure 4.

It can be observed that corrosion tendency persist after 7 days of immersion in corrosive solutions. The values of corrosion rate were close for both type of steel tested in acid solution, $4.5255 \mathrm{~g} / \mathrm{m}^{2} \cdot \mathrm{h}$ for DX51D and $4.5184 \mathrm{~g} / \mathrm{m}^{2} \cdot \mathrm{h}$ for S220GD. The smaller value of corrosion rate was found in $0.5 \mathrm{M}$ $\mathrm{NaCl}$ for DX51D, $0.1385 \mathrm{~g} / \mathrm{m}^{2}$.h. For other solutions corrosion rate was found at close values.

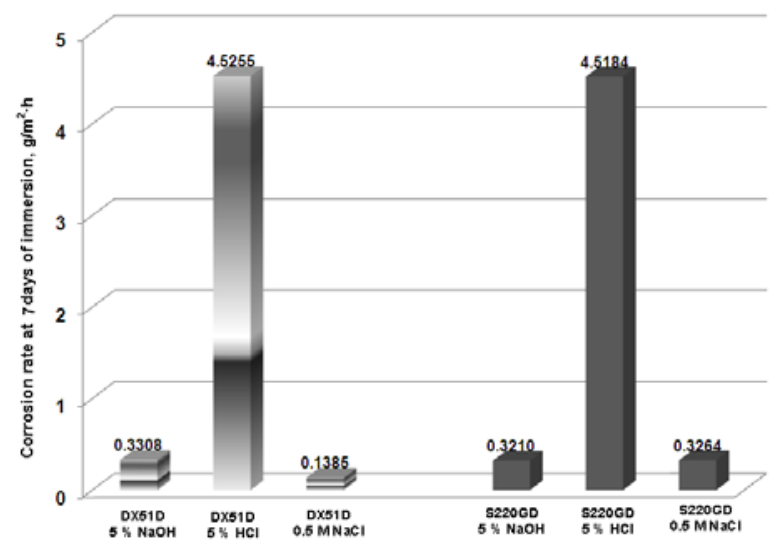

Figure 3. Corrosion rate of tested steels after 7 days of immersion in different corrosive solutions

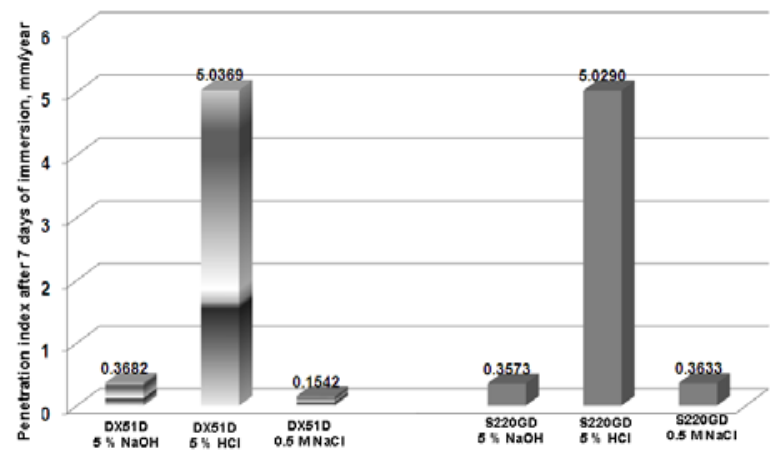

Figure 4. Penetration index of tested steels after 7 days of immersion in different corrosive solutions

The values of corrosion rate after 7 days of immersion are smaller than after 3 days, maybe because on the surfaces of steel appear oxides or other compounds that have an anticorrosion effect.

Figure 5 and Figure 6 present the corrosion rate and penetration index of tested steel after 14 days of immersion in corrosive solutions.

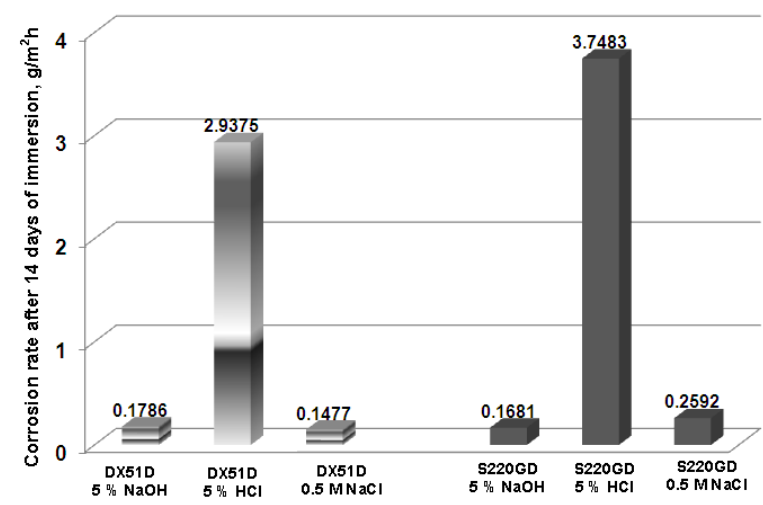

Figure 5. Corrosion rate of tested steels after 14 days of immersion in different corrosive solutions 
"Mircea cel Batran" Naval Academy Scientific Bulletin, Volume XIX - 2016 - Issue 1

Published by "Mircea cel Batran" Naval Academy Press, Constanta, Romania // The journal is indexed in:

PROQUEST / DOAJ / DRJI / JOURNAL INDEX / I2OR / SCIENCE LIBRARY INDEX / Google Scholar / Crossref /

Academic Keys / ROAD Open Access / OAJI / Academic Resources / Scientific Indexing Services / SCIPIO

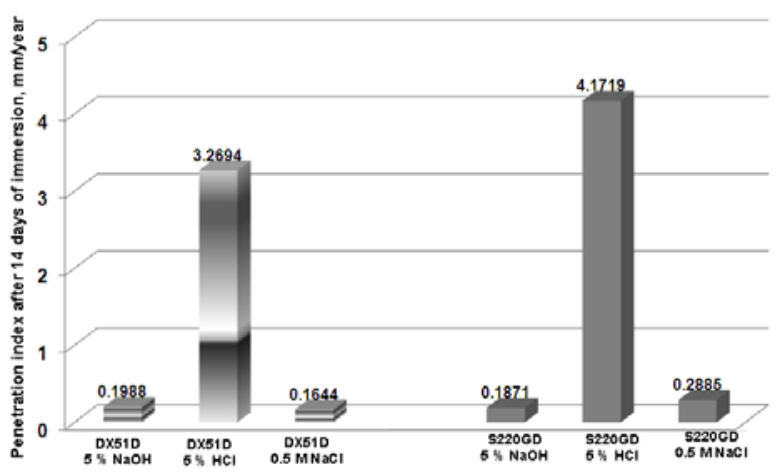

Figure 6. Penetration index of tested steels after 14 days of immersion in different corrosive solutions

From the values founded for corrosion rate and penetration index after 14 days of immersion in corrosive solutions of steel tested samples it was observed that S220GD has a higher corrosion rate than DX51D in $5 \% \mathrm{HCl}$. The values were 3.7483 $\mathrm{g} / \mathrm{m}^{2} \cdot \mathrm{h}$ and $2.9375 \mathrm{~g} / \mathrm{m}^{2} \cdot \mathrm{h}$, respectively. Other higher values of corrosion rate and penetration index were found for steel S220GD in $0.5 \mathrm{M} \mathrm{NaCl}$. For others samples tested in different corrosive environments the values of corrosion rate and penetration index have close values.

In Figure 7 and Figure 8 were presented the corrosion rate and penetration index for tested samples after 21 days of immersion in corrosive solutions.

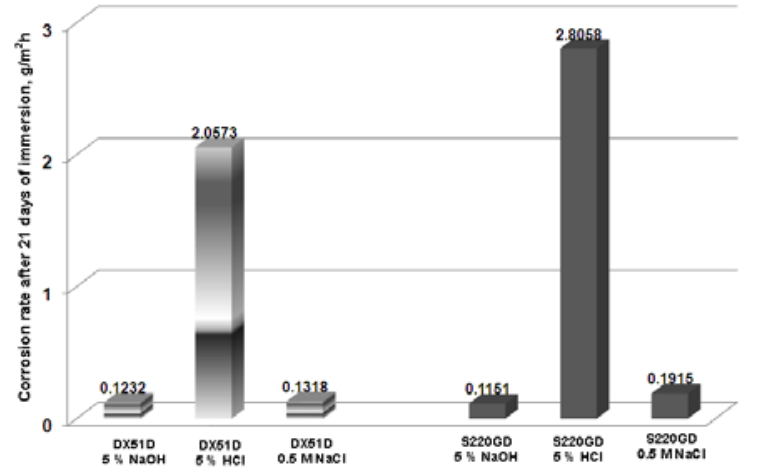

Figure 7. Corrosion rate of tested steels after 21 days of immersion in different corrosive solutions

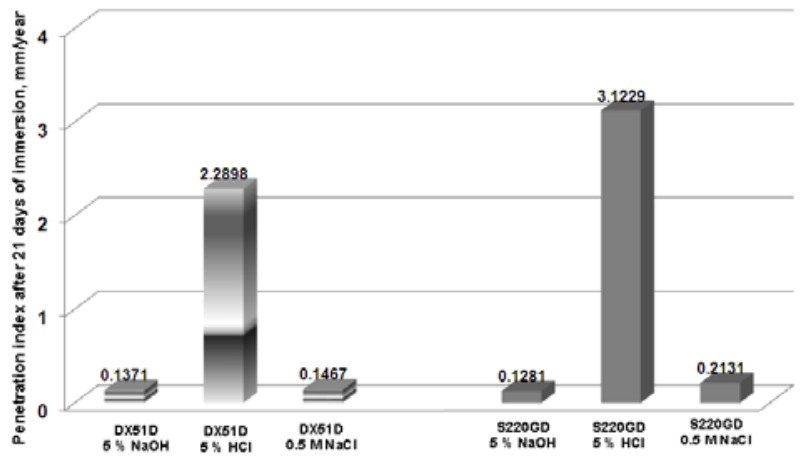

Figure 8. Penetration index of tested steels after 21 days of immersion in different corrosive solutions

It necessary to notice that both types of steel tested was totally destroyed in $5 \% \mathrm{HCl}$ solution after 21 days of immersion. The values of corrosion rate and penetration index were found higher in this corrosive solution compare with values in the other corrosive solutions tested. The corrosion tendency in $0.5 \mathrm{NaCl}$ it was maintained, corrosion rate have a value of $0.1915 \mathrm{~g} / \mathrm{m}^{2} \cdot \mathrm{h}$ for steel sample S220GD. The values obtained for corrosion rate and penetration index for DX51D in $5 \% \mathrm{NaOH}$ and $0.5 \mathrm{M} \mathrm{NaCl}$ and for S220GD in 5\% $\mathrm{NaOH}$ were close values.

Figure 9 and Figure 10 presents the corrosion rate and penetration index of steel types DX51D and S220GD after 28 days of immersion in $5 \% \mathrm{NaOH}$ and $0.5 \mathrm{M} \mathrm{NaCl}$.

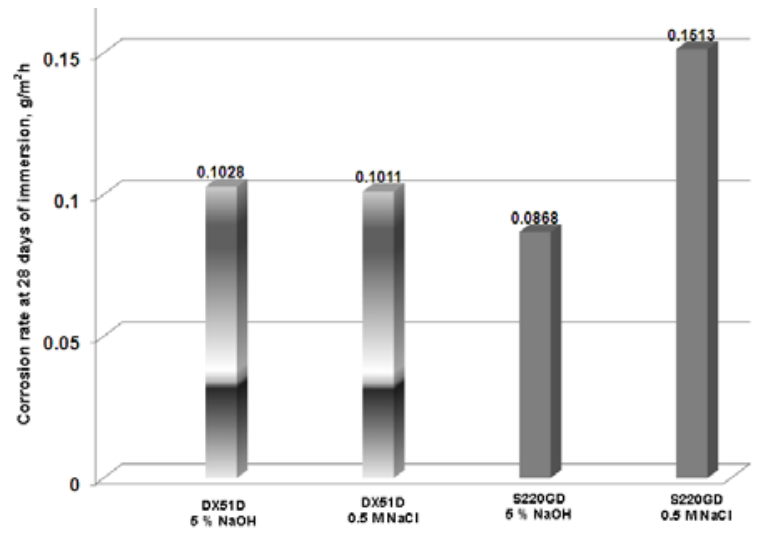

Figure 9. Corrosion rate of tested steels after 28 days of immersion in different corrosive solutions 
"Mircea cel Batran" Naval Academy Scientific Bulletin, Volume XIX - 2016 - Issue 1

Published by "Mircea cel Batran" Naval Academy Press, Constanta, Romania // The journal is indexed in: PROQUEST / DOAJ / DRJI / JOURNAL INDEX / I2OR / SCIENCE LIBRARY INDEX / Google Scholar / Crossref /

Academic Keys / ROAD Open Access / OAJI / Academic Resources / Scientific Indexing Services / SCIPIO

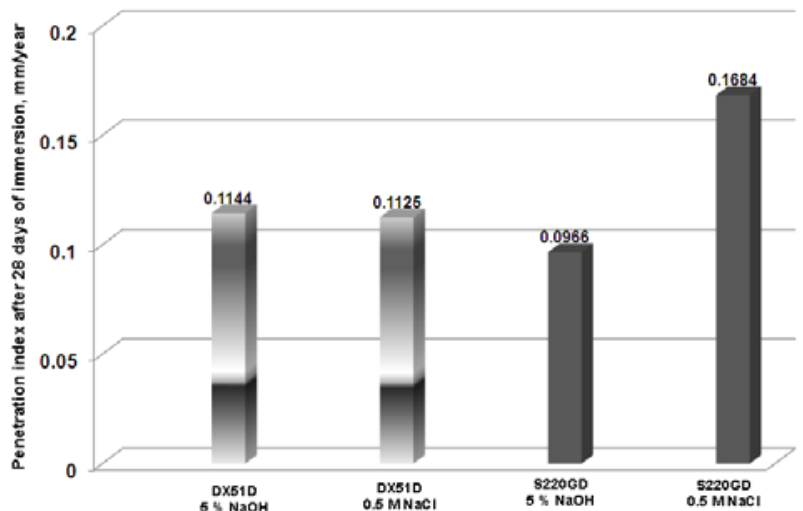

Figure 10. Penetration index of tested steels after 28 days of immersion in different corrosive solutions

From the values shows in Figures 9 and 10, it can be concluded that the corrosion tendency of the steel sample S220GD in $0.5 \mathrm{M} \mathrm{NaCl}$ after 28 days of immersion remained the same as in 21 days. In this case the value of corrosion rate is the biggest $0.1513 \mathrm{~g} / \mathrm{m}^{2} \cdot \mathrm{h}$ and the penetration index has a value of $0.1684 \mathrm{~mm} / \mathrm{year}$. Close values of corrosion rate were found for steel DX51D samples in $5 \% \mathrm{NaOH}\left(0.1028 \mathrm{~g} / \mathrm{m}^{2} \cdot \mathrm{h}\right)$ and $0.5 \mathrm{M}$ $\mathrm{NaCl}$ solutions $\left(0.1011 \mathrm{~g} / \mathrm{m}^{2} \cdot \mathrm{h}\right)$. The lowest value of corrosion rate was found for steel sample of S220GD in basic medium $\left(0.0868 \mathrm{~g} / \mathrm{m}^{2} \cdot \mathrm{h}\right)$.

The values of corrosion rate and penetration index for 28 days of immersion have a different trend for steel tested samples. For steel DX51D it found a decrease of values of corrosion rate in 28 days in $5 \% \mathrm{NaOH}$ and $5 \% \mathrm{HCl}$. In $0.5 \mathrm{M} \mathrm{NaCl}$ solution it was observed an increase of the corrosion rate values in 14 days of immersion and after that a decrease of the corrosion rate values in time, till 28 days. The values of corrosion rate for steel S220GD maintained the same trend in 28 days of immersion in corrosive solutions. These values decrease in time for steel S220GD in all corrosive solution tested.

Figures 11 and 12 presents the visual aspects of steel samples tested after 28 days of immersion in different corrosion environments. Corrosion behaviour of steel tested samples it could be caused by formation of passive and anticorrosive layers of oxides or other compounds on the surfaces. For a better understanding of these processes is necessary to continue the investigation with analyze the morphology of the tested surfaces after different time of immersion and evaluate types of the corrosion products and their composition in corrosive solutions.

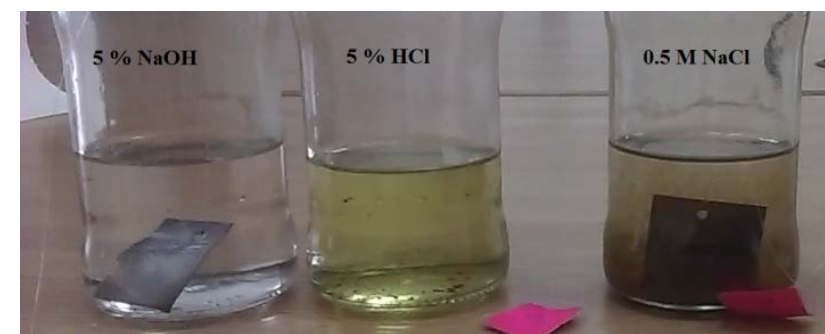

Figure 11. Visual aspect of steel DX51D after 28 days of immersion in corrosive environments

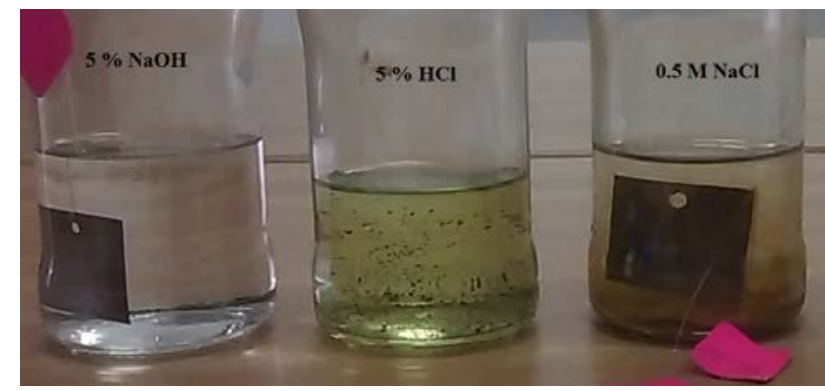

Figure 12. Visual aspect of steel S220GD after 28 days of immersion in corrosive environments

From the values of penetration index founded for all tested samples it was evaluate the corrosion tendency of carbon steel DX51D and hot-dip galvanized steel S220GD in $5 \% \mathrm{NaOH}, 5 \% \mathrm{HCl}$ and $0.5 \mathrm{M} \mathrm{NaCl}$ solutions. The results are presented in Table 1.

Table 1. Corrosion tendency of steel tested samples for 28 days in different corrosion solutions

\begin{tabular}{|c|c|c|c|c|c|c|}
\hline \multirow{2}{*}{$\begin{array}{c}\text { Days of } \\
\text { immersion }\end{array}$} & \multicolumn{5}{|c|}{ Corrosion stability coefficient } \\
\cline { 2 - 7 } & \multicolumn{2}{|c|}{ Steel DX51D } & \multicolumn{3}{c|}{ Steel S220GD } \\
\cline { 2 - 7 } & $\begin{array}{c}5 \% \mathrm{H} \\
\mathrm{NaOH}\end{array}$ & $\begin{array}{c}0.5 \mathrm{HCl} \\
\mathrm{NaCl}\end{array}$ & $\begin{array}{c}5 \% \\
\mathrm{NaOH}\end{array}$ & $\begin{array}{c}5 \% \\
\mathrm{HCl}\end{array}$ & $\begin{array}{c}0.5 \mathrm{M} \\
\mathrm{NaCl}\end{array}$ \\
\hline 3 & 7 & 9 & 5 & 6 & 9 & 6 \\
\hline 7 & 6 & 9 & 6 & 6 & 9 & 6 \\
\hline 14 & 6 & 8 & 6 & 6 & 8 & 6 \\
\hline 21 & 6 & 8 & 6 & 6 & 8 & 6 \\
\hline 28 & 6 & - & 6 & 5 & - & 6 \\
\hline
\end{tabular}

The carbon steel DX51D has a medium corrosion resistance in $5 \% \mathrm{NaOH}$, the value of corrosion stability coefficient is 7 after 3 days and decrease to 6 after 28 days of immersion. In $5 \% \mathrm{HCl}$ corrosion stability coefficient is 9 after 7 days, decrease to 8 after 28 days of immersion so that it can be concluded that DX51D has a lower corrosion resistance in acid medium. A better corrosion resistance for this type of steel was recorded in $0.5 \mathrm{M} \mathrm{NaCl}$ solution. In 3 days the steel is stable to corrosion with a corrosion stability coefficient equal with 5 , but in 28 days stability decrease, the value of corrosion stability 


\begin{abstract}
"Mircea cel Batran" Naval Academy Scientific Bulletin, Volume XIX - 2016 - Issue 1
Published by "Mircea cel Batran" Naval Academy Press, Constanta, Romania /I The journal is indexed in:

PROQUEST / DOAJ / DRJI / JOURNAL INDEX / I2OR / SCIENCE LIBRARY INDEX / Google Scholar / Crossref /

Academic Keys / ROAD Open Access / OAJI / Academic Resources / Scientific Indexing Services / SCIPIO
\end{abstract}

coefficient became 6 and steel DX51D present a medium corrosion resistance in saline solution.

For conventional hot-dip galvanized steel S220GD it was observed that corrosion stability coefficient in $5 \% \mathrm{NaOH}$ was 6 for 21 days of immersion and decrease to 5 after another one weak. From these values it can conclude that steel S220GD has a medium corrosion resistance after 21 days of immersion in $5 \% \mathrm{NaOH}$ and become stable, resistant to corrosion in 28 days. In $5 \% \mathrm{HCl}$ solution the corrosion stability coefficient is 9 after 7 days and 8 after 28 days, so that this type of steel has a lower corrosion resistance in $5 \% \mathrm{HCl}$ solution in tested period of time. In saline environment steel S220GD has a value of corrosion stability coefficient equal with 6 on entire period of time. It can be concluded that steel S220GD has a medium corrosion resistance in 0.5 $\mathrm{M} \mathrm{NaCl}$ for 28 days of immersion.

For further works the authors intends to analyze the morphological aspects of the steel tested samples surfaces in 28 days of immersion in $5 \%$ $\mathrm{NaOH}, 5 \% \mathrm{HCl}$ and $0.5 \mathrm{M} \mathrm{NaCl}$. Another investigation intends to identify and quantify the corrosion products after different time of immersion in corrosive solutions.

\title{
CONCLUSIONS
}

After 3 days of immersion in corrosive solutions carbon steel DX51D and conventional hot-dip galvanized steel S220GD has a higher corrosion rate in $5 \% \mathrm{HCl}$. A good corrosion resistance after 3 days was found for steel DX51D in $0.5 \mathrm{M} \mathrm{NaCl}$.

In 7 days of immersion it was observed the same corrosion behaviour in $5 \% \mathrm{HCl}$ and a high value of corrosion rate for steel DX51D in basic solution.

Corrosion behaviour in $5 \% \mathrm{HCl}$ maintains the same after 14 days of immersion. It was found a higher corrosion rate of steel S220GD in $0.5 \mathrm{M} \mathrm{NaCl}$. For another samples tested in corrosive solutions the values of corrosion rate were very close.

Steels DX51D and S220GD were totally corroded after 21 days of immersion in $5 \% \mathrm{HCl}$. In others corrosive solutions the corrosion rate has close values with a high value in $0.5 \mathrm{M} \mathrm{NaCl}$ for steel S220GD.

After 28 days of immersion it was observe a higher corrosion rate for steel S220GD in $0.5 \mathrm{M} \mathrm{NaCl}$ solution. For other samples tested in different corrosive solutions the corrosion rate has close values.

From the values of corrosion stability coefficient it could be conclude that a medium corrosion resistance was found for carbon steel DX51D and hot-dip galvanized steel S220GD in $5 \% \mathrm{NaOH}$ and $0.5 \mathrm{M} \mathrm{NaCl}$.

\section{BIBLIOGRAPHY}

[1] Soares C.G., Garbatov Y., Zayed A., Wang G., Influence of environmental factors on corrosion of ship structures in marine atmosphere, Corrosion Science, Volume 51, Issue 9, pp. 2014-2026, 2009;

[2] Potecaşu O., Potecaşu F., Bordei M., Alexandru P., Marin F., The corrosion behavior of steel for transportation of petroleum products in marine environment, International Multidisciplinary Scientific GeoConference, SGEM2013, Conference Proceedings, ISBN 978-954-91818-8-3 / ISSN 1314-2704, June 16-22, Vol. 2, pp. 981 - 988, 2013;

[3] Bhandari J., Khan F., Abbassi R., Garaniya V., Ojeda R., Modelling of pitting corrosion in marine and offshore steel structures, A technical review, Journal of Loss Prevention in the Process Industries 37, pp. 39-62, 2015;

[4] Rios E.C., Zimer A.M., Pereira E.C., Mascaro L.H., Analysis of AISI 1020 steel corrosion in seawater by coupling electrochemical noise and optical microscopy, Electrochimica Acta 124, pp. 211-217, 2014;

[5] Hong J.H., Lee S.H., Kim J.G., Yoon J.B., Corrosion behaviour of copper containing low alloy steels in sulphuric acid, Corrosion Science, Volume 54, pp 174-182, 2012;

[6] Xu L., Guo S., Chang W., Chen T., Hu L., Lu M., Corrosion of Cr bearing low alloy pipeline steel in $\mathrm{CO}_{2}$ environment at static and flowing conditions, Applied Surface Science, Volume 270, pp. 395-404, 2013;

[7] Soriano C., Alfantazi A., Corrosion behavior of galvanized steel due to typical soil organics, Construction and Building Materials 102, pp. 904-912, 2016;

[8] Seré P.R., Deyá C., Elsner C.I., Di Sarli A.R., Corrosion of painted galvanneal steel, Procedia Materials Science 8, pp. 1-10, 2015;

[9] Negm N.A., Kandile N.G, Badr E.A., Mohammed M.A., Gravimetric and electrochemical evaluation of environmentally friendly nonionic corrosion inhibitors for carbon steel in $1 \mathrm{M} \mathrm{HCl}$, Corrosion Science, Volume 65, pp. 94-103, 2012;

[10] Shaban S.M., Abd-Elaal A.A, Tawfik S.M., Gravimetric and electrochemical evaluation of three nonionic dithiol surfactants as corrosion inhibitors for mild steel in $1 \mathrm{M} \mathrm{HCl}$ solution, Journal of Molecular Liquids 216 , pp. 392-400, 2016; 
"Mircea cel Batran" Naval Academy Scientific Bulletin, Volume XIX - 2016 - Issue 1

Published by "Mircea cel Batran" Naval Academy Press, Constanta, Romania /I The journal is indexed in: PROQUEST / DOAJ / DRJI / JOURNAL INDEX / I2OR / SCIENCE LIBRARY INDEX / Google Scholar / Crossref I

Academic Keys I ROAD Open Access / OAJI / Academic Resources / Scientific Indexing Services / SCIPIO

[11] Singh A.K., Mohapatra S., Pani B., Corrosion inhibition effect of Aloe Vera gel: Gravimetric and electrochemical study, Journal of Industrial and Engineering Chemistry 33, pp. 288-297, 2016;

[12] Vermesan H., Corrosion and corrosion protection, Publisher Risoprint, Cluj-Napoca, ISBN 978-973-751690-9, 2008;

[13] Paweł Żwirek, Statistical research of steel grades: DX51D, DX52D and DX53D, Technical Transactions Civil Engineering, 4-B/2014;

[14] Akpan I. A., Offiong N. O., Electrochemical and gravimetric studies of the corrosion inhibition of mild steel in $\mathrm{HCl}$ medium by cephalexin drug, American Journal of Chemistry and Materials Science, 1(1), pp. 16, 2014;

[15] Sherif El-Sayed M., Electrochemical and Gravimetric Study on the Corrosion and Corrosion Inhibition of Pure Copper in Sodium Chloride Solutions by Two Azole Derivatives, International Journal of Electrochemistry Science 7, pp. 1482 - 1495, 2012;

[16] Badea T., Popa M., Nicola M., Ştiinţa şi ingineria coroziunii, Ed. Academiei Române, Bucureşti, ISBN 973-27-0856-5, 2002. 